УДК 342.5(043.2)

DOI https://doi.org/10.32849/2663-5313/2020.9.10

\title{
Павло Прохоров,
}

аспірант кафедри иивільного прочесу

Наиіонального університету «Одеська юридична академія»,

суддя

Київсъкого районного суду міста Одеси

\section{НАРАДЧА КІМНАТА: СУЧАСНА НЕОБХІДНІСТЬ ЧИ «РУДИМЕНТ» МИНУЛОГО?}

Перебування суду у нарадчій кімнаті під час прийняття рішення є як запорукою конституиійної гарантї принципу незалежності суду від стороннього впливу на процес прийняття рішення, так і певним чинником дискомфорту для суддів, пов'язаного з деякими певними обмеженнями та відсутністю законодавчого закріплення необхідних умов для перебування судді. му та практичному аспектах автором розглянуті питання доиільності видалення суду до нарадчоі кімнати для прийняття процедурного або остаточного процесуального рішення в прочесі розгляду справ, віднесених до категорії цивільної юрисдикиії.

Глибокий аналіз положень статей цивільного процесуального законодавства наводить до пере конливого висновку про надмірну формалізованість судового проиесу, яка призводить до необгрунтованого проиесуального навантаження на суди та суддів, затягування часу фактичного розгляду справ у судах різних інстаниій, ускладнення доступу громадян до правосуддя та, відповідно, до зменшення довіри суспільства до судової системи України. Серед переліку прочесуальних дій, що здійснюються суддею протягом перебування у нарадиій кімнаті для прийняття законного і обгрунтованого судового рішення на підставі наявних у справі доказів, визначено можливість суду або судді прийняти прочесуальне рішення, не видаляючись до нарадчої кімнати - протокольно.

У статті сформульовано пропозицію щодо удосконалення щивільного процесуального законодавства під час прийняття проиесуального рішення. Пропонується надати можливість суду самостійно вирішувати залежно від характеру справи, обсягу та складності поставлених питань та наявних у справі доказів, чи слід виходити до нарадчої кімнати, чи можливо одразу в судовому засіданні прийняти рішення, а згодом викласти його в письмовій формі та надати сторонам по справі, тим більше якщо справа розглядається складом суду не колегіально, а одноособово.

Ключові слова: процедурне питання, ухвала суду, рішення суду, судове рішення, нарадча кімната, суд, суддя.

Постановка проблеми. Сьогодні місцевими загальними судами України розглядаються сотні тисяч цивільних справ на рік. У кожній цивільній справі у справах позовного провадження учасниками справи $€$ сторони (позивач або відповідач), третя особа, а у справах наказного та окремого провадження - заявники, боржники та інші заінтересовані особи.

Кожна справа для їі учасника є чимось «особистим», прийняте рішення у якій змінює його життєвий уклад, має для нього позитивні або негативні наслідки. Так і для судді, жодна судова справа не є шаблонною, та хоча вона і не є для нього чимось особистим, все ж вимагає певного досвіду, індивідуального підходу, повного дослідження іï обставин, наданих сторонами доказів та пояснень, а також прийняття рішення, яке де-факто $є$ його особистим висновком, що грунтується на внутрішньому переконанні судді відносно фактичних та правових обставин справи.
Через це суддя не може розглядати кожну справу за одним шаблоном дій. Сдиним орієнтиром, дотримання якого є обов'язковим у такому разі, є тільки норми цивільного процесуального закону, яких суддя повинен сумлінно дотримуватись, аби результат розгляду справи був таким, що відповідає вимогам законності.

Так, судом або суддею ухвалюються не тільки рішення, якими закінчується розгляд справи по суті, які, до речі, приймаються тільки в нарадчій кімнаті, а також приймаються процедурні рішення, пов'язані з рухом справи в суді, які вирішуються шляхом постановлення ухвал.

Кожен вихід суду до нарадчої кімнати для вирішення справи по суті або для вирішення процедурного питання - це комплекс дій судді, пов'язаний з переміщенням із зали судового засідання до спеціально обладнаного приміщення (нарадчої кімнати) для вирішення питання, задля якого суд вида- 
лявся до нарадчої кімнати, його викладення у письмовій та електронній формах, повернення до зали судового засідання та проголошення судового рішення.

Весь цей комплекс дій судді займає час, час судді, у якого в цей день може бути призначена велика кількість інших судових засідань, та час учасників процесу, які теж чекають поки суддя повернеться 3 нарадчої кімнати та проголосить прийняте ним рішення, попри те, що досить часто і сам суддя і учасники процесу вже наперед фактично розуміють, яке рішення буде прийнято судом, якщо воно є безспірним в розумінні його відповідності вимогам закону або чітко регламентованим.

Актуальність теми полягає в тому, що цей надлишковий формалізм Цивільного процесуального кодексу в реаліях теперішніх умов здійснення правосуддя цивільними судами потребує перегляду та реформування - необхідно надати суддям можливість на свій власний розсуд вирішувати, чи слід видалятися суду до нарадчої кімнати, чи можливо проголосити про прийняте рішення, а згодом викласти його у письмовій формі з посиланням на норми права.

Аналіз останніх досліджень та публікацій. Проблемні аспекти видалення суду до нарадчої кімнати нерозривно пов'язані із питанням винесення судового рішення. Значним внеском у розвиток теорії судових рішень $є$ наукові праці таких авторів, як С. Абрамов, І. Андронов, М. Гурвич, Е. Демський, А. Клейнман, В. Комаров, М. Курило, В. Тертишніков, Н. Чечіна, Д. Чечот, П. Шевчук, М. Штефан, В. Ярков, М. Ясинок та інші.

Метою дослідження є системне вивчення та правовий аналіз інституту нарадчої кімнати у порівнянні із сучасними реаліями цивільного судочинства в українських судах першої інстанції та актуальна необхідність реформування надлишково-формалізованого процесу розгляду цивільних справ.

Виклад основного матеріалу. На цей час чинний Цивільний процесуальний кодекс України передбачає такі види судових рішень: 1) ухвали; 2) рішення; 3) постанови; 4) судові накази.

Майже всі судові рішення приймаються судами в нарадчій кімнаті.

Інститут таємниці нарадчої кімнати народився як невіддільна частина суду присяжних. Заборона присяжним залишати нарадчу кімнату доки не буде досягнуто згоди та прийнятий вердикт про винуватість або невинуватість складає надзвичайно важливий компонент діяльності вказаного суду [1, с. 172].
Для належного розуміння, що саме робить суд у нарадчій кімнаті, слід розібратися 3 поняттям «нарадча кімната». Нормами чинних процесуальних кодексів України в жодній статті не наводиться поняття нарадчої кімнати, так само як і багато науковців в своїх наукових працях, не вдаючись до визначення змісту поняття, лише зазначають про ті дії, яких суддя повинен у ній дотримуватись, або навпаки, які суддя не може вчиняти в нарадчій кімнаті.

Так, наприклад, М.П. Курило вважає, що нарадча кімната - це спеціальне, передбачене процесуальними нормами права приміщення, у межах якого продовжується судове засідання в закритій формі, де принцип гласності судового засідання не діє [2, с. 58].

Якщо умовно уявити, що це за приміщення, можна дійти висновку, що це кімната або спеціально обладнане приміщення суду, в якому склад суду (головуючий суддя або колегія суддів) постановляє (оформлює письмово і підписує) вирок, виносить рішення, ухвалу або постанову у справі.

Також можна погодитись з М.П. Курило, що в цьому приміщенні не діє принцип гласності. Навіть більше, можливо додати, що спеціальний статус цього приміщення означає відсутність доступу до нього жодної особи, окрім складу суду, та його спеціальний інформаційний захист з боку держави.

Чинним українським законодавством висуваються певні вимоги до нарадчої кімнати. Так, за ДБН 2.2-26:2010 «Будинки і споруди. Суди» - нарадча кімната належить до категорії допоміжних приміщень залів судових засідань. Вона повинна бути у кожному залі судових засідань, примикати до залу з боку процесуальної зони і мати окремий вхід, розташований так, щоб під час руху судді не контактували з учасниками судового процесу та відвідувачами. В кожній нарадчій кімнаті повинен бути санітарний вузол площею не менше 2,0 кв. м., а сама площа нарадчої кімнати не повинна бути меншою за 9,0 кв. м. при залах судових засідань з розгляду цивільних справ [3].

Судді повинні суворо дотримуватися таємниці нарадчої кімнати. Під час ухвалення судового рішення ніхто не має права перебувати в нарадчій кімнаті, крім складу суду, який розглядає справу. Вихід судді 3 нарадчої кімнати до проголошення судового рішення може мати місце під час перерви для відпочинку (протягом робочого часу та після його закінчення) [4, с. 4].

Отже, перебування суду у нарадчій кімнаті має на меті забезпечити невіддільний та обов'язковий складник незалежності суддів як конституційного принципу організа- 
ції та функціонування судів у професійній діяльності суддів.

У нарадчій кімнаті можуть знаходитись лише судді, які входять до складу суду по справі, жодна стороння особа, в тому числі помічник судді або секретар судового засідання, не мають права знаходитись у нарадчій кімнаті [5, с. 117].

Неможливо не погодитись із такою думкою автора, однак тут варто зазначити, що досить багато науковців дотримуються однакової думки про те, що нарадча кімната не повинна бути обладнана засобами телефонного зв'язку, що пов'язано з логічним висновком унеможливлення спілкування суду з іншими особами з метою збереження принципу таємниці нарадчої кімнати, відсутності впливу на суддів та взагалі - ізоляцією суду від навколишнього світу під час перебування в нарадчій кімнаті.

Водночас необхідно звернути увагу і на те, що автори статей та наукових праць, як і сам законодавець, в жодному науковому дослідженні або нормативному акті не зазначають про вимоги для належного обладнання нарадчої кімнати. Так, дійсно, в нарадчій кімнаті передбачено санітарний вузол, а в іншій частині увага фокусується на обмеженнях, дотримання яких вимагає нарадча кімната. Разом з тим поза увагою залишаються інші потреби складу суду, судді чи суддів, аби здійснювати свої повноваження в гідних умовах. Наприклад, слід було б звернути увагу законодавця на необхідність обладнання нарадчої кімнати такими елементарними та обов'язковими складниками, потрібними для написання тексту рішення з посиланням на законодавчі акти, як комп'ютер, принтер, доступ до мережі «Інтернет» та системи електронного документообігу суду тощо. Крім того, окремої уваги заслуговують і питання створення комфортних умов перебування суддів у нарадчій кімнаті, зокрема, забезпечення кондиціонування та опалення приміщення, забезпечення доступу до питної води та створення умов для прийняття їжі, адже ситуація, коли суддя перебуває у нарадчій кімнаті тривалий час, за який відповідні біологічні потреби виникають об'єктивно, є розповсюдженою, а вихід з нарадчої кімнати задля їх задоволення може бути оцінений як порушення її таємниці.

Ці всі обставини потребують теоретикоправового дослідження та нормативного врегулювання.

Отже, перебування суду у нарадчій кімнаті під час прийняття рішення є як запорукою конституційної гарантії принципу незалежності суду від стороннього впливу на процес прийняття рішення, так і певним чинником дискомфорту для суддів, пов'язаного 3 деякими певними обмеженнями та відсутністю законодавчого закріплення необхідних умов для перебування судді передусім як людини у зачиненому зсередини приміщенні. Попри це, відповідно до вимог цивільного процесуального законодавства вихід до нарадчої кімнати є процесуальним обов'язком для суду, і судді зобов'язані чітко та неухильно його дотримуватись у своїй повсякденній діяльності.

Як зазначає Г.П. Тимченко, завершення судових дебатів підводить суд до винесення й оголошення судового рішення, при цьому судовий розгляд в кімнаті для нарад продовжується, і лише після оголошення рішення суду і закриття судового засідання розгляд можна вважати повністю завершеним [6, с. 44].

3 такою думкою автора можливо беззаперечно погодитись, оскільки стадія виходу суду до нарадчої кімнати є обов'язковою частиною цивільного процесу під час прийняття рішення по суті справи, а саме судове засідання не переривається на вказаній стадії цивільного процесу, оскільки після повернення з нарадчої кімнати суд одразу починає проголошувати судове рішення, і лише після його проголошення можливо стверджувати про завершення розгляду справи по суті.

Так, відповідно доч. 1 ст. 244 ЦПК України після судових дебатів суд виходить до нарадчої кімнати для ухвалення рішення, оголосивши орієнтовний час його проголошення, а в частинах 1 та 2 ст. 259 ЦПК зазначено про те, що рішення та постанови суди ухвалюють іменем України негайно після закінчення судового розгляду, які приймаються, складаються та підписуються складом суду в нарадчій кімнаті, однак у ч. 4 зазначеної статті надається можливість суду постановити ухвалу суду, не виходячи до нарадчої кімнати, окрім тих ухвал, які постановляються окремим процесуальним документом [7]

У цих статтях законодавець чітко регламентує порядок, згідно з яким рішення суду, яким закінчується розгляд справи, приймається судом тільки в нарадчій кімнаті. Жодного виключення в процедурі прийняття рішення по суті справи, як і альтернативи щодо його прийняття, немає. Водночас законодавець надає можливість суду самому вирішувати питання чи виходити суду до нарадчої кімнати для прийняття так званого процедурного рішення в формі ухвали, якою не закінчується розгляд справи по суті, чи вирішити питання протокольно. 
Тобто в практичному аспекті у суду є два можливі варіанти дій

1) Приймаючи рішення по суті справи, тобто те рішення, яким закінчується розгляд справи, суд зобов'язаний вийти до нарадчої кімнати;

2) Приймаючи так звані ухвали 3 процедурних питань, пов'язані з рухом справи, якими не закінчується розгляд справи по суті, суд може сам вирішити, виходити до нарадчої кімнати чи ні, однак з певним застереженням, якщо цей процесуальний документ не передбачає письмової форми його викладення.

Таким чином, якщо звернутися до першого варіанту прийняття рішення судом, перед науковцями та діючими суддями постає певна проблематика. Так, вихід суду до нарадчої кімнати дійсно є безумовною гарантією відсутності впливу на суд, цей інститут використовується досить давно в багатьох державах світу, він покликаний уберегти суддів від впливу заінтересованих осіб на суть вирішення спору шляхом унеможливлення їхнього доступу до суддів, відсутності спілкування або іншої комунікації із суддею в період його перебування в нарадчій кімнаті, а відтак і від вчинення тиску на суддю в будь-який спосіб. Однак проблематика виникає і через інші обставини, а насамперед через перевантаженість судів. Так, судді розглядають сотні, а інколи і тисячі справ протягом року. До кожної справи суддя підходить індивідуально, справедливо, неупереджено та дотримується принципу іiі своєчасного розгляду. Після проведення судових дебатів суд виходить до нарадчої кімнати для прийняття рішення, де суд оцінює надані сторонами докази та приймає рішення на підставі внутрішнього переконання, після чого повинен викласти його в письмовій формі. Враховуючи тривалий час написання повного тексту рішення, відповідно до ст. 268 ЦПК України суд може проголосити його вступну та резолютивну частини з повідомленням осіб про дату складання повного рішення, але навіть така спрощена процедура, як складання та проголошення лише вступної та резолютивної частини рішення, теж вимагає затрат значного проміжку часу від судді, оскільки ЦПК України висуває певні вимоги до написання зазначених частин.

Так, за діючим цивільним процесуальним кодексом України у вступній частині рішення зазначаються: номер справи; дата і місце ухвалення рішення; найменування суду, що ухвалив рішення; склад суду; прізвище та ініціали секретаря судового засідання; ім'я сторін та інших учасників справи та їх представників; вимоги позивача.
У резолютивній частині рішення зазначаються висновок суду про задоволення або відмову в задоволенні позову повністю або частково щодо кожної з заявлених вимог; розподіляються судові витрати; зазначається строк і порядок набрання рішенням суду законної сили та порядок його оскарження; зазначаються найменування сторін та інших учасників справи, їх місцезнаходження або місце проживання чи перебування, ідентифікаційний код юридичної особи, реєстраційний номер облікової картки платника податків сторін або номер і серія паспорта. Крім того, в резолютивній частині в разі необхідності також може бути вказано про: порядок, строк або забезпечення виконання рішення; відстрочення або розстрочення його виконання; повернення судового збору; призначено дату, час і місце судового засідання для вирішення питання про судові витрати; дату складення повного судового рішення.

Тобто судді слід дотримуватись багатьох процесуальних вимог для правильного складання короткого тексту рішення, що потребує тривалого часу написання, навіть не кажучи про те, що за такого швидкого написання і браку часу доволі часто судом допускаються орфографічні та технічні помилки під час написання рішення, які потребують виправлення, що знову ж таки призводить до додаткового навантаження на суддю.

Окремо слід зазначити, що після судових дебатів та до виходу суду до нарадчої кімнати в більшості випадків кваліфікований суддя вже розуміє, яке рішення він прийме у нарадчій кімнаті, оскільки в його свідомості завдяки його високому професіоналізму та практичним навичкам вже склалася уява про надані докази та пояснення сторін, вони умовно оцінені в його розумінні, особливо якщо справа не є складною, а до нарадчої кімнати виходить склад суду в особі одного судді, а не колегії суддів, та судді немає з ким радитись. На думку автора цієї статті, у такому разі суд може прийняти законне і обгрунтоване судове рішення, не виходячи до нарадчої кімнати та не витрачаючи час на таку формальну процедуру, як складання і написання короткого тексту рішення. На жаль, процесуальний закон такої можливості суду не надає.

Наприклад, суд розглядає справу про розірвання шлюбу, в якій після закінчення строку, наданого судом для примирення сторін за заявою відповідача, який заперечує проти задоволення позову, позивач наполягає на поданій ним позовній заяві та просить розірвати шлюб, а відповідач продовжує заперечувати проти розірвання шлюбу та просить відмовити в задоволенні позову. 
Зрозуміло, що фактично суд не може прийняти іншого рішення, окрім задоволення позову та розірвання шлюбу, однак, знаючи про це, суд все одно повинен дотриматись занадто ускладненої та формалізованої процедури - вийти до нарадчої кімнати, написати вступну та резолютивну частину рішення, перевірити ії на наявність технічних та орфографічних помилок, виправити їх, якщо вони є, внести короткий текст рішення суду в базу даних документообігу суду Д-3, підписати та направити в Сдиний державний реєстр судових рішень, роздрукувати оригінал та дві копії «короткого тексту» (оригінал долучити до матеріалів справи, а дві копії надати сторонам по справі), підписати текст рішення, завірити його дві копії для сторін, повернутися 3 нарадчої кімнати та проголосити вступну та резолютивну частину рішення суду - що займає доволі значний проміжок часу та його зайве витрачання.

У цьому автор статті пропонує змінити цивільно-процесуальне законодавство та надати можливість суду проголошувати резолютивну частину судового рішення одразу після закінчення судових дебатів, не виходячи при цьому до нарадчої кімнати, а повний текст рішення суду виготовляти у чітко обумовлений законом строк.

3 цією метою пропонується внести такі зміни в ЦПК України та викласти їх у такій редакції:

1) ч. 1 ст. 244 - після судових дебатів, суд, не виходячи до нарадчої кімнати, проголошує резолютивну частину рішення суду, в якій зазначає про наслідки розгляду щодо кожної з заявлених вимог. Питання розподілу судових витрат вирішуються судом під час складання повного тексту рішення. В разі необхідності суд виходить до нарадчої кімнати для ухвалення рішення, оголосивши орієнтовний час його проголошення.

Стосовно ухвал суду 3 процедурних питань, пов'язаних з рухом справи, якими не закінчується розгляд справи по суті, варто зазначити наступне.

Так, під час вирішення питання в процесі розгляду цивільних справ перед суддями доволі часто постають питання, які необхідно вирішувати в процесуальному руслі. Зазвичай це заяви або клопотання, подані сторонами по справі з метою вирішення тих чи інших обставин.

Тут можна навести як приклад цивільні справи щодо визнання права власності на спадкове майно. В процесі розгляду зазначеної категорії справ суди зазвичай повинні досліджувати спадкові справи, заведені після смерті спадкодавця. В процесі розгляду цивільних справ вказаної категорії сторони звертаються до суду з заявою про витребу- вання доказів, а саме копії спадкової справи, заведеної у нотаріуса. В цьому разі перед судом не стоїть питання про доцільність витребовування вказаної справи з метою встановлення об'єктивної істини та повноти дослідження всіх обставин справи та перевірки їх доказами, оскільки це є обов'язком суду. Однак, маючи зазвичай безспірну заяву про витребування доказів, суд повинен вийти до нарадчої кімнати, знаючи про те, що вказану заяву в будь-якому разі слід задовольнити, провести вищезазначений у вказаній статті перелік дій в нарадчій кімнаті, після чого повернутися з нарадчої кімнати, проголосити прийняте ним рішення із вказаного питання і продовжити розгляд справи або відкласти їі для отримання витребовуваних відомостей. I тут варто зазначити про те, що протягом одного судового засідання таких питань, заявлених різними сторонами, може виникнути декілька, і кожен раз суддя повинен проводити зазначену процедуру повторно.

У вказаній статті пропонуються такі зміни в ЦПК України та їх викладення у такій редакції:

1) ч. 4 ст. 259 - ухвали суду можуть бути постановлені судом в судовому засіданні, не виходячи до нарадчої кімнати, де суд проголошує резолютивну частину ухвали суду, в якій зазначає про наслідки розгляду щодо кожної з заявлених вимог. Якщо ухвала суду повинна бути оформлена окремим документом, повний текст такої ухвали повинен бути складений протягом п'яти днів 3 дня оголошення резолютивної частини ухвали.

$\mathrm{У}$ цьому разі пропонується саме надати суду вибір:

- або вийти до нарадчої кімнати, прийняти рішення у вигляді вступної та резолютивної частини ухвали та відповідно до вимог ч. 6 ст. 259 ЦПК України протягом п’яти днів скласти її повний текст чи одразу у нарадчій кімнаті скласти її повний текст;

- або не виходити до нарадчої кімнати, в судовому засіданні прийняти рішення, оголосити про наслідки розгляду поставленого перед судом питання та протягом п'яти днів скласти повний текст такої ухвали 3 посиланням на підстави задоволення або відмови в задоволенні кожної із вимог.

\section{Висновки}

Отже, інститут виходу суду до нарадчої кімнати є фінальною стадією судового засідання по справі. Після проведення судових дебатів суд виходить до нарадчої кімнати, де спілкування суду із сторонами по справі та іншими учасниками судового процесу закінчується, суддя ізолюється від навколишнього світу задля забезпечення фундаментального та конституційного принципу 
незалежності суду і поринає в глибокий аналіз досліджених доказів, на підставі якого приймає рішення по справі. Однак у сьогоднішніх реаліях інститут нарадчої кімнати не завжди є доречним, він, як вбачається повинен мати не імперативний, а диспозитивний характер. Суд сам повинен вирішувати залежно від розуміння характеру справи, обсягу та складності поставлених питань та наявних у справі доказів, чи слід суду виходити до нарадчої кімнати, чи можливо одразу в судовому засіданні прийняти рішення, а згодом викласти його в письмовій формі та надати сторонам по справі, тим більше якщо справа розглядається складом суду не колегіально, а одноособово. В практичному значенні вказані зміни покликані розвантажити суддів та пришвидшити розгляд справ у місцевих та апеляційних судах.

\section{Список використаних джерел:}

1. Смолькова I.В. Тайна совещания судей и особое мнение судьи. Вестник ОГУ. 2006. № 3. C. $172-175$.
2. Курило М.П. Судові рішення в різних галузях процесуального права: можливості уніфікації. Науковий вісник Міжнародного гуманітарного університету. Сер.: Юриспрудениія. 2013. № 6-1. Том № 2. С. $57-60$.

3. ДБН 2.2-26:2010 Будинки і споруди. Суди. URL: http://www.minregion.gov.ua/wp-content/ uploads/2017/12/72.1.-DBN-V.2.2-262010.-Skan.Budinki-i-sporudi.-Sudi.pdf.

4. «Про судове рішення у цивільній справі»: Постанова Пленуму Верховного суду України № 14 від 18.12.2009 року (п. 16). Вісник Верховного суду України. 2010 р. № 1.

5. Смолькова I.В. Тайна совещания судей как гарантия законности, обоснованности и справедливости приговора. Сибирские уголовно-проиессуальные и криминалистические чтения. № 2 (16). 2017. C. $116-122$

6. Тимченко Г.П. Винесення і оголошення рішення суду в цивільному, господарському та адміністративному судочинстві України. Міждисииплінарні гуманітарні студіі. Серія: Правничі науки. 2014 р. Вип. 1. С. 44-50.

7. Цивільний процесуальний кодекс України. BВP 2004 р. № 40-41, 42. Ст. 492.

Pavlo Prokhorov. Deliberation room: modern necessity or "rudiment" of the past?

The presence of judges in the deliberation room during the decision-making process is both a prerequisite of the constitutional guarantee of the principle of independence of the court from outside influence on the decision-making process, and a certain factor of discomfort for judges due to certain restrictions and lack of necessary conditions enshrined in law for stay of a judge there. In the article in theoretical and practical aspects the author examines the expediency of retiring of judges to deliberation room for taking a procedural or final procedural decision in the course of consideration of the cases falling into the category of civil jurisdiction.

An in-depth analysis of the provisions of the articles of civil procedural law leads to a convincing conclusion about the excessive formalization of a trial, which leads to unreasonable procedural burden on courts and judges, delaying the actual consideration of cases in courts of different instances, complicated citizens' access to public justice and, accordingly, a decrease of public confidence in the judicial system of Ukraine. Among the list of procedural actions performed by a judge during his/her stay in the deliberation room aimed at making a lawful and reasonable court decision on the basis of available evidence in the case, the possibility for the judges or a judge to make a procedural decision without retiring to the deliberation room - by way of record of judgment was established.

The article formulates a proposal to improve the civil procedural legislation relating to making a procedural decision. It is proposed to provide the court with the opportunity to decide independently, depending on the nature of the case, the scope and complexity of the issues raised and the evidence available in the case, whether to retire to the deliberation room, whether it is possible to make a decision immediately in court session and later put it in writing and provide it to the parties to the case, especially if the case is considered not by the panel of judges, but by one judge.

Key words: procedural issue, court ruling, court decision, judgment, deliberation room, court, judge. 